\title{
Poly (ADP-Ribose) Polymerase Inhibitor
}

National Cancer Institute

\section{Source}

National Cancer Institute. Poly (ADP-Ribose) Polymerase Inhibitor. NCI Thesaurus. Code C62554.

Any substance that inhibits Poly (ADP-Ribose) polymerase, an enzyme involved in detecting DNA single strand breaks and the initiation of DNA repair. Inhibition of Poly (ADP-Ribose) polymerase has direct cytotoxic effects by inhibiting DNA repair and causing cell death. 